\title{
Fetal Tracheal Occlusion in Lambs with Congenital Diaphragmatic Hernia: Role of Exogenous Surfactant at Birth
}

\author{
ANDREANA BÜTTER, IOANA BRATU, HÉLÈNE FLAGEOLE, JEAN-MARTIN LABERGE, \\ LAJOS KOVACS, DANIEL FAUCHER, AND BRUNO PIEDOBOEUF
}

\begin{abstract}
Division of Pediatric Surgery [A.B., I.B., H.F., J.-M.L.], Montréal Children's Hospital, McGill University
Health Centre; Department of Pediatrics [L.K., D.F.], Sir Mortimer B. Davis Jewish General Hospital and the McGill University Health Centre, Montréal, Québec, Canada, H3H 1P3; Department of Pediatrics [B.P.], Centre de Recherche du Centre Hospitalier Universitaire de Québec, Université Laval, Sainte-Foy, Québec, Canada, G1V $4 G 2$
\end{abstract}

\begin{abstract}
Fetal tracheal occlusion (TO) has been used to reverse the lung hypoplasia associated with congenital diaphragmatic hernia (CDH). However, TO has a detrimental effect on type II pneumocyte function and surfactant production. Previously, we have shown that in surgically created CDH lambs, TO improved markedly the response to resuscitation even though the lungs remain surfactant deficient. The goal of this investigation was to assess the effects of exogenous surfactant administered at birth to $\mathrm{CDH}$ lambs with or without fetal TO during $8 \mathrm{~h}$ of resuscitation. Lambs were divided into five groups: $\mathrm{CDH}, \mathrm{CDH}+$ surfactant (SURF), $\mathrm{CDH}+\mathrm{TO}, \mathrm{CDH}+\mathrm{TO}+\mathrm{SURF}$, and nonoperated controls. A left-sided $\mathrm{CDH}$ was created in fetal lambs at $80 \mathrm{~d}$ gestation. TO was performed at $108 \mathrm{~d}$, and the lambs were delivered by hysterotomy at $136 \mathrm{~d}$. Bovine lipid extract surfactant was administered before the first breath and again at $4 \mathrm{~h}$ of life. All CDH+SURF lambs, but only three of five CDH lambs, survived up to $8 \mathrm{~h}$. When compared with the corresponding nonsurfactant-treated group, surfactant-treated $\mathrm{CDH}$ and
\end{abstract}

\section{ABSTRACT}

$\mathrm{CDH}+\mathrm{TO}$ lambs did not demonstrate improved alveolar-arterial oxygen gradients, $\mathrm{pH}$, or $\mathrm{PCO}_{2}$. In fact, in the $\mathrm{CDH}+\mathrm{TO}$ group, surfactant treatment significantly worsened ventilation efficiency as measured by the ventilation efficiency index. The observed improvement in pulmonary compliance secondary to surfactant treatment was not significant. This investigation demonstrates that prophylactic surfactant treatment at birth does not improve gas exchange or ventilation efficiency in $\mathrm{CDH}$ lambs with or without TO. (Pediatr Res 58: 689-694, 2005)
Abbreviations
$\mathbf{A a D O}_{2}$, alveolar-arterial oxygen gradient
CDH, congenital diaphragmatic hernia
$\mathbf{P a C O}_{2}$, partial pressure of arterial carbon dioxide
$\mathrm{PaO}_{2}$, partial pressure of arterial oxygen
SURF, surfactant
TO, tracheal occlusion
VEI, ventilation efficiency index

The high mortality rate associated with $\mathrm{CDH}$ is related to its complex pathophysiology. Pulmonary hypoplasia, pulmonary hypertension, decreased pulmonary compliance, and surfactant deficiency may all contribute to hypoxemia, hypercarbia, and acidosis. These factors stimulate pulmonary artery vasoconstriction, creating a cycle of worsening pulmonary hypertension, right-to-left shunting, and further physiologic deterioration of blood gases (1-3).

Received January 10, 2005; accepted February 3, 2005

Correspondence: Jean-Martin Laberge, M.D., The Montréal Children's Hospital, 2300 Tupper St., Suite C-1129, Montréal, QC, Canada, H3H 1P3; e-mail: jean-martin. laberge@muhc.mcgill.ca

This work was supported by the Canadian Institute of Health Research, the Foundation for Research into Children's Diseases, and BLES Biochemical Inc. BP was supported by an award from the Fonds de Recherche en Santé du Québec.

DOI: 10.1203/01.PDR.0000180534.42731.95
Both the surgically created $\mathrm{CDH}$ animal model as well as human neonates with $\mathrm{CDH}$, have significantly increased lung growth after fetal TO compared with their $\mathrm{CDH}$-only counterparts (4-6). In addition, this fetal surgical intervention prevents excess pulmonary artery muscularization in fetal $\mathrm{CDH}$ lambs by thinning the medial area of small pulmonary arteries (7). These structural changes decrease pulmonary hypertension and improve gas exchange, ventilation, and compliance. However, TO in intact fetal lungs is associated with a dramatic decrease in the number and function of type II pneumocytes, the cells that produce lung surfactant $(8-11)$.

Both $\mathrm{CDH}$ lambs and rats are believed to be surfactant deficient $(4,12,13)$. Although the hypoplastic lungs of lambs, induced by lung liquid drainage, are associated with a higher density of type II pneumocytes (14), the function of these pneumocytes at birth appears impaired. Moreover, surfactant 
protein mRNA expression in lung homogenates is decreased (15). This observation is consistent with data showing a decrease in the concentration of phospholipids and surfactant proteins recovered by bronchoalveolar lavage (BAL) (4). There is controversy concerning the surfactant status of human newborn infants with $\mathrm{CDH}$. Surfactant deficiency in $\mathrm{CDH}$ infants was suggested by Glick et al. (16) when they showed clinical improvement in three patients after exogenous surfactant administration. However, this result is confounded because two out of the three infants were premature. In contrast, Ijsselstijn et al. (17) showed that $\mathrm{CDH}$ patients have a similar surfactant phospholipid concentration as various control patients. However, an alternate report from Asabe et al. (18) suggests that the protein content of surfactant is abnormal in human $\mathrm{CDH}$ patients.

Antenatal steroid administration benefits lung development and maturation in both lambs with surgically created $\mathrm{CDH}$ $(19,20)$ and rats with pharmacologically induced CDH $(21)$. However, the beneficial effect of steroids may be independent from their effect on surfactant (22-27). Indeed, we have shown that despite antenatal treatment with steroids, lambs with $\mathrm{CDH}$ or $\mathrm{CDH}+\mathrm{TO}$ remain markedly surfactant deficient at birth (4). However, we have also observed that CDH lambs with TO have a marked and sustained improvement in oxygenation and VEI over an 8-h resuscitation period (28). In contrast, complete recovery of the expression of mRNA for surfactant proteins $\mathrm{B}$ and $\mathrm{C}$ in lambs with $\mathrm{CDH}$, but not in lambs with $\mathrm{CDH}$ and $\mathrm{TO}$, was observed after a short period of resuscitation $(28,29)$.

Exogenous surfactant can be administered to neonates prophylactically (before the first breath) or as "rescue therapy" (after the appearance of respiratory distress symptoms). In lambs and humans with $\mathrm{CDH}$, prophylactic surfactant administration has been shown to significantly improve gas exchange and lung mechanics $(16,30)$. However, the absence of control groups combined with the short duration of the experiments in lambs, and the presence of prematurity along with the lack of appropriate controls in the small human study, make the significance of these changes difficult to assess. In contrast, rescue surfactant therapy does not improve gas exchange or compliance in either animals or humans with $\mathrm{CDH}(31,32)$. Prophylactic surfactant is thought to distribute itself more evenly throughout the lung as aeration has not yet taken place $(33,34)$.

Permissive hypercapnia and other modalities have increased the survival of neonates with $\mathrm{CDH}$ in the past decade (35). Further improvement will require a combination of various treatment strategies. The goal of this study was to assess the benefit of prophylactic surfactant treatment in $\mathrm{CDH}$ lambs with and without $\mathrm{TO}$ over an 8 -h resuscitation period.

\section{MATERIALS AND METHODS}

Ethics approval for all animal experiments was obtained from the McGill University Animal Care Committee. Methods for this study, with the exception of the exogenous surfactant portion, were similar to those previously published by our group (28). The $\mathrm{CDH}, \mathrm{CDH}+\mathrm{TO}$, and control groups were the same animals used in our previous study (28).

Fetal lamb interventions. A left-sided diaphragmatic hernia was created in fetal lambs at $80 \mathrm{~d}$ gestation as described previously (36). Fetal tracheoscopy (2.7 mm Semi Flexible Mini-Endoscope, Karl Storz GmbH \& Co., Tuttlingen Germany) was used in combination with a detachable balloon system (GVB12
Latex Goldvalve Balloon, diameter $14 \mathrm{~mm}$, length $22.5 \mathrm{~mm}$, volume $2.5 \mathrm{~mL}$; CCOXLS co-axial catheters) to achieve TO at $108 \mathrm{~d}$ gestation (37). At $129 \mathrm{~d}$ gestation, all ewes, including the control group, received $250 \mathrm{mg}$ medroxyprogesterone intramuscularly (i.m.) to decrease the incidence of preterm labor (38); and at $135 \mathrm{~d}$ gestation, they received $0.5 \mathrm{mg} / \mathrm{kg}$ betamethasone i.m. to accelerate lung development and maturation (39). Careful assessment of lung growth, lung development, surfactant content, and vascular remodeling in lambs killed at birth following a similar antenatal protocol was published previously $(4,7)$.

Ex-utero intrapartum treatment (EXIT). While under maternal inhalational anesthesia with the placental circulation maintained, the fetal lambs underwent a limited neck dissection to permit cannulation of both the right common carotid artery (preductal) and internal jugular vein. A tracheostomy was performed through which a 4-mm uncuffed endotracheal tube was inserted. The fetus was then disconnected from placental circulation and ventilated for up to $8 \mathrm{~h}$.

Surfactant supplementation. The first dose of of BLES (bovine lipid extract surfactant) $(15 \mathrm{~mL}$, approximately $5 \mathrm{~mL} / \mathrm{kg}$ ) (BLES Biochemical Inc, London, ON, Canada) was given through an $8 \mathrm{~F}$ feeding tube positioned just above the carina during the EXIT procedure when the lamb was still connected to its placental circulation. Then, the endotracheal tube was occluded until delivery. A second dose of BLES $(5 \mathrm{~mL} / \mathrm{kg})$ was given at $4 \mathrm{~h}$ of life. Given that $\mathrm{CDH}$ lambs with TO were still profoundly surfactant deficient after $8 \mathrm{~h}$ of resuscitation as measured by their surfactant protein $\mathrm{C}$ content (28) and given the known deleterious effects that ventilation and hyperoxia have on surfactant (40-43), we decided to administer this second dose of surfactant to maximize the chance of obtaining a sustained improvement. The lamb was disconnected from the ventilator and manually ventilated for $30 \mathrm{~s}$. Surfactant was administered in three aliquots with the lamb in the following positions: on the left side, on the right side, and supine. After delivery of each aliquot, the lamb was manually ventilated for $1 \mathrm{~min}$. Upon completion of surfactant delivery, the lamb's endotracheal tube was reconnected to the ventilator.

Eight-hour resuscitation. Sedation was achieved with ketamine $2 \mathrm{mg} / \mathrm{kg} / \mathrm{h}$ (i.v.), paralysis with pancuronium $0.1 \mathrm{mg} / \mathrm{kg} / \mathrm{h}$ (i.v.), and alkalosis with sodium bicarbonate $0.5 \mathrm{mmol} / \mathrm{kg} / \mathrm{h}$ (i.v.). We used the following initial ventilator settings (Sechrist Infant Ventilator Model IV-100B, Sechrist Industries, Anaheim, CA) with the permitted range in parentheses: peak inspiratory pressure (PIP) $25 \mathrm{~cm} \mathrm{H}_{2} \mathrm{O}$ (15-30); peak end-expiratory pressure (PEEP) $5 \mathrm{~cm} \mathrm{H}_{2} \mathrm{O}$ (3-7); $\mathrm{FiO}_{2} 1.0$ (0.21-1.0); respiratory rate (RR) 120 breaths per minute $(10-120)$; minimum inspiratory time $0.25 \mathrm{~s}$; inspiratory time to expiratory time ratio (I:E) 1:1. Ventilator settings were changed accordingly if $\mathrm{PaCO}_{2}>65 \mathrm{~mm}$ $\mathrm{Hg}$ or $\mathrm{PaCO}_{2}<40 \mathrm{~mm} \mathrm{Hg}$; if $\mathrm{PaO}_{2}<40 \mathrm{~mm} \mathrm{Hg}$ or $\mathrm{PaO}_{2}>100 \mathrm{~mm} \mathrm{Hg}$; and if $\mathrm{pH}<7.4$ or $\mathrm{pH}>7.5$. We calculated the correction necessary to bring the $\mathrm{pH}$ up to 7.4 and gave boluses of $2 \mathrm{mmol} / \mathrm{kg}$ of $\mathrm{NaHCO}_{3}$ (i.v.) to increase the $\mathrm{pH}$ by 0.1 unit. Tension pneumothoraces were treated with chest tubes, including subxiphoid incisions. Preductal arterial blood gases were analyzed using a portable clinical analyzer and EG7 + cartridges (i-STAT, Sensor Devices Inc., Waukesha, WI).

Outcome measures. Oxygenation and ventilation parameters were calculated as follows: $\mathrm{AaDO}_{2}=\left[\left(\left(713 \times \mathrm{FiO}_{2}\right)-\mathrm{PaCO}_{2}\right) / 0.8\right]-\mathrm{PaO}_{2} ; \mathrm{VEI}=$ $3800 /\left[\right.$ PIP - PEEP) $\times$ respiratory rate $\left.\times \mathrm{PaCO}_{2}\right](44,45)$.

Statistical analysis. Five groups were compared: $\mathrm{CDH}(n=5)$, $\mathrm{CDH}+\mathrm{SURF}(n=4), \mathrm{CDH}+\mathrm{TO}(n=5), \mathrm{CDH}+\mathrm{TO}+\mathrm{SURF}(n=6)$, and nonoperated controls (Cont) $(n=4)$. For longitudinal data, a repeated measure analysis procedure (SAS, SAS Institute, Cary, NC) was used to assess the effect of time between groups (treatment by time interaction). In the case of missing values, we used the previous value. For $\mathrm{PCO}_{2}, \mathrm{pH}, \mathrm{AaDO}_{2}$, and VEI, the amount of missing values was $<4 \%$, which included the missing values for the lambs that died before the end of the 8-h resuscitation protocol. For the compliance data, due to technical difficulties, the amount of missing values was $10 \%$, including three lambs for which no measure of compliance was available (two $\mathrm{CDH}$ and one control). For nonlongitudinal data, a one-way ANOVA test with treatment as a factor was used. Four post hoc comparisons were performed. The effects of surfactant treatment on $\mathrm{CDH}$ were assessed by comparing i) $\mathrm{CDH}$ with $\mathrm{CDH}+\mathrm{SURF}$, and ii) $\mathrm{CDH}+\mathrm{SURF}$ with controls. The effects of surfactant treatment in $\mathrm{CDH}+\mathrm{TO}$ were assessed by comparing iii) $\mathrm{CDH}+\mathrm{TO}$ with $\mathrm{CDH}+\mathrm{TO}+\mathrm{SURF}$, and iv) $\mathrm{CDH}+\mathrm{TO}+\mathrm{SURF}$ with controls. For comparison between $\mathrm{CDH}, \mathrm{CDH}+\mathrm{TO}$, and controls, the reader should refer to our previous publication (28). The Bonferroni procedure was used in the case of multiple comparisons. Data are presented as the mean \pm SEM.

\section{RESULTS}

The in utero mortality rates for both sets of experiments were $\leq 35 \%$ in the different experimental groups. This is less than the commonly reported rate of $50 \%$ (12). 
Only animals with a diaphragmatic defect and herniated viscera in the left chest at the time of autopsy were considered as $\mathrm{CDH}+\mathrm{TO}+\mathrm{SURF}$ lambs. One animal was excluded due to inadequate $\mathrm{CDH}$.

All 10 lambs in both SURF groups survived the 8-h resuscitation period. In contrast, only three of the five $\mathrm{CDH}$-only lambs survived (Table 1). The need for chest tube placement to treat tension pneumothoraces was also recorded (Table 1). None of the control animals required chest tubes. In contrast, all CDH-only animals required chest tubes, and three of five $\mathrm{CDH}+\mathrm{TO}$ lambs had chest tubes in place. The addition of exogenous surfactant appeared to decrease the incidence of pneumothoraces, although this could not be shown as being statistically significant due to the small numbers of animals per group. Three of the four $\mathrm{CDH}+\mathrm{SURF}$ lambs required chest tubes whereas only two of the six $\mathrm{CDH}+\mathrm{TO}+\mathrm{SURF}$ animals required chest tubes.

Both $\mathrm{CDH}$ and $\mathrm{CDH}+\mathrm{SURF}$ lungs were hypoplastic with wet lung weight/body weight (LW/BW) ratios of $1.11 \pm$ $0.12 \%$ and $0.99 \pm 0.14 \%$, respectively (Fig. 1). TO + SURF significantly increased the LW/BW ratio $(\mathrm{CDH}+\mathrm{TO}: 2.39 \pm$ $0.42 \%$ and $\mathrm{CDH}+\mathrm{TO}+\mathrm{SURF}: 2.14 \pm 0.23 \%$ ) of $\mathrm{CDH}$ animals to values comparable to those of controls $(1.73 \pm 0.04 \%)$ (Fig. 1). More complete studies looking at lung growth, lung development, surfactant content, and vascular remodeling in lambs killed at birth after a similar antenatal protocol have been published previously $(4,7)$.

Arterial $\mathrm{pH}$, but not $\mathrm{PaCO}_{2}$, significantly improved after surfactant administration in the $\mathrm{CDH}$-only group (Fig. 2, $A$ and $B$, Table 2). In contrast, $\mathrm{pH}$ and $\mathrm{PCO}_{2}$ failed to improve in the group of lambs with $\mathrm{CDH}+\mathrm{TO}+\mathrm{SURF}$ when compared with $\mathrm{CDH}+\mathrm{TO}$ (Fig. 2B, Table 2). In fact, after $180 \mathrm{~min}$ of resuscitation, both $\mathrm{pH}$ and $\mathrm{PCO}_{2}$ had worsened with surfactant supplementation after TO; however, this difference was not significant ( $p>0.05$ ) (Fig. 2, $A$ and $B$, Table 2).

Oxygenation, as calculated by $\mathrm{AaDO}_{2}$, did not improve with surfactant treatment in any of the two groups (Fig. $2 C$, Table 2). Ease of ventilation, as measured by an increased VEI, was not improved with the addition of surfactant. In fact, the VEI was significantly worse in the $\mathrm{CDH}+\mathrm{TO}+\mathrm{SURF}$ group when compared with the $\mathrm{CDH}+\mathrm{TO}$ group (Fig. 2D, Table 2). Pulmonary compliance was lowest for the $\mathrm{CDH}$-only group throughout the resuscitation period (Fig. 3). Surfactant administration appears to improve compliance. The $\mathrm{CDH}+\mathrm{SURF}$ group maintained higher compliance than the $\mathrm{CDH}$ group, reaching levels similar to the control group. $\mathrm{CDH}+\mathrm{TO}+\mathrm{SURF}$ lambs had the highest compliance. However, none of these differences proved to be statistically significant owing to the

Table 1. Survival and Barotrauma

\begin{tabular}{lccc}
\hline Experimental Group & $\begin{array}{c}\text { Survived } \\
8 \text { hours }\end{array}$ & $\begin{array}{c}\text { Age at death } \\
\text { (hours) }\end{array}$ & Chest tube \\
\hline CDH & $3 / 5$ & 5,7 & $5 / 5$ \\
CDH + SURF & $4 / 4$ & n/a & $3 / 4$ \\
CDH + TO & $5 / 5$ & $n / a$ & $3 / 5$ \\
CDH + TO + SURF & $6 / 6$ & $\mathrm{n} / \mathrm{a}$ & $2 / 6$ \\
Control & $4 / 4$ & $\mathrm{n} / \mathrm{a}$ & $0 / 4$ \\
\hline
\end{tabular}

$\mathrm{p}>0.05$ for all comparisons, n/a: not applicable. large differences among individuals of the same group and the limited number of animals in some groups.

\section{DISCUSSION}

In this investigation, we demonstrate that prophylactic delivery of exogenous surfactant at birth significantly worsens the physiologic/clinical response to resuscitation in lambs with $\mathrm{CDH}+\mathrm{TO}$. However, our results do suggest that surfactant treatment does marginally improve the response to respiratory gas exchange in lambs with $\mathrm{CDH}$.

We have shown previously that fetal TO induces lung growth that reverses pulmonary hypoplasia associated with $\mathrm{CDH}$ (4). In addition, TO prevents excess pulmonary muscularization, which is associated with pulmonary hypertension at birth (7). The combination of these effects on lung growth and vascular remodeling leads to improved gas exchange and ventilation (28).

Unfortunately, TO accelerates lung growth at the expense of type II cell accumulation (8-11). We have shown that release of TO combined with antenatal steroid treatment can prevent this decrease in type II pneumocyte density in fetal lambs with normal lungs $(46,47)$. However, the situation with hypoplastic lungs in CDH cases is more complex. These lungs have a higher density of type II pneumocytes, even though the phospholipid content of the BAL or levels of surfactant proteins and mRNA expression in lung tissue are decreased at birth $(4,15)$. In CDH lambs, TO decreases the density of type II pneumocytes to control levels (intact fetuses) but worsens the abnormalities in surfactant production despite the use of antenatal steroids (4). However, after short-term resuscitation, recovery of mRNA expression of surfactant proteins $\mathrm{B}$ and $\mathrm{C}$ was observed in lambs with $\mathrm{CDH}$ and $\mathrm{CDH}+\mathrm{TO}$ with release of tracheal (TR) occlusion $1 \mathrm{wk}$ before delivery, but not in lambs with $\mathrm{CDH}+\mathrm{TO}$ only (without release) $(28,29)$. However, in our previous study, the $\mathrm{CDH}+\mathrm{TO}$ group did significantly better for the VEI and $\mathrm{AaDO}_{2}$ than the $\mathrm{CDH}+\mathrm{TO}+\mathrm{TR}$ in spite of similar lung growths (28). In fact, the $\mathrm{CDH}+\mathrm{TO}$ lambs did as well as the controls for those parameters. However, all of the lambs were delivered at $137 \mathrm{~d}$ gestation $($ term $=145 \mathrm{~d}$ ) and, therefore, even the control lambs may have had insufficient surfactant to cope with air breathing because of their relatively young gestational age. Indeed, a relatively elevated $\mathrm{AaDO}_{2}$ gradient in the control group was observed.

In the present investigation, we have demonstrated that prophylactic surfactant fails to improve both gas exchange and ventilation over an 8 -h resuscitation period in $\mathrm{CDH}$ lambs with TO. In fact, by $240 \mathrm{~min}$, marked improvement of the VEI was observed in the $\mathrm{CDH}+\mathrm{TO}$ group and in untouched control lambs, whereas the $\mathrm{CDH}+\mathrm{TO}+\mathrm{SURF}$ group fared as badly as the $\mathrm{CDH}$ alone. This may be a consequence of both the volume of surfactant given and its method of administration. The second dose of surfactant was calculated based on lamb body weight rather than on lung weight and, thus, was an overestimation of the amount of surfactant required. Consequently, this second dose may have "drowned" the lungs, rendering gas exchange and ventilation more difficult. In addition, the latter dose of surfactant required manual bagging and changing the 


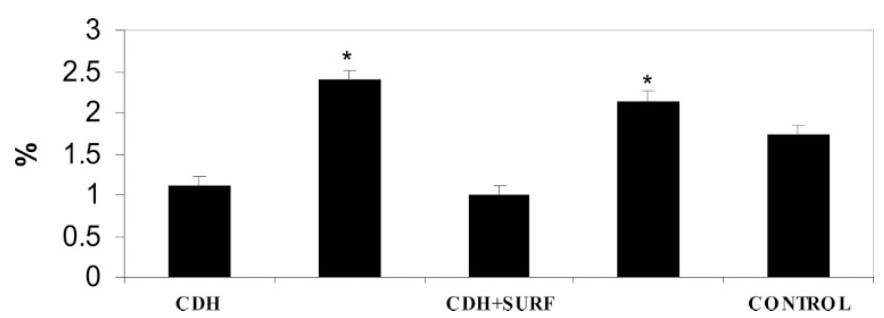

Figure 1. Lung weight/body weight. Five groups were compared: congenital diaphragmatic hernia ( $\mathrm{CDH}, n=5), \mathrm{CDH}+$ surfactant $(\mathrm{CDH}+\mathrm{SURF}, n=4)$, $\mathrm{CDH}+$ tracheal occlusion $(\mathrm{CDH}+\mathrm{TO}, n=5), \mathrm{CDH}+\mathrm{TO}+\mathrm{SURF} n=6)$, and non-operated controls (Control, $n=4)$. Data is presented as mean \pm SEM where $*=$ different from $\mathrm{CDH} \pm \operatorname{SURF}(p<0.05)$.

position of the animal. Even though this dose was administered rapidly over 3-5 min, the lungs of these $\mathrm{CDH}$ lambs may be very sensitive to any manipulation. $\mathrm{CDH}+\mathrm{TO}+\mathrm{SURF}$ lambs continued to demonstrate high $\mathrm{PacO}_{2}$ levels for the remaining $4 \mathrm{~h}$ of resuscitation whereas the control group showed marked improvement. In contrast, the $\mathrm{CDH}+\mathrm{TO}$ group had a notable decrease of $\mathrm{PaCO}_{2}$ levels after $240 \mathrm{~min}$, similar to the one observed in control lambs (28). Thus, the addition of exogenous surfactant to TO appeared detrimental with regard to hypercarbia in this model.

Our study failed to demonstrate significant positive effects of surfactant treatment on the compliance. The absence of significant differences could be explained by the relatively small groups and the high variation of the measured values within each group (SEM). In addition, the total respiratory compliance measurements may underestimate changes in lung compliance due to interference with other elements of the respiratory system, such as thoracic rigidity and the presence of intestines in the thoracic cavity. However, the apparent reduction in the mortality rate and the decreased incidence of pneumothoraces

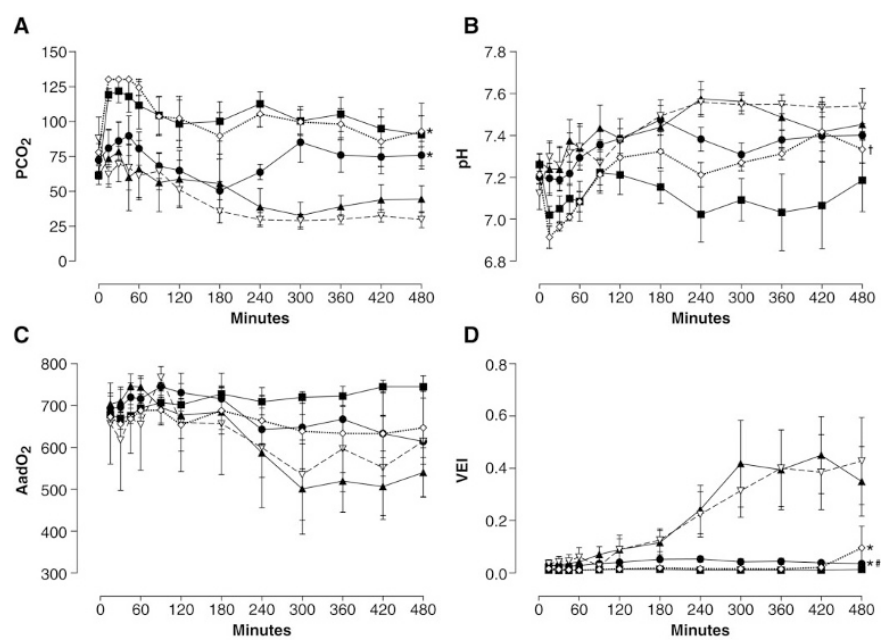

Figure 2. Response of $\mathrm{pCO}_{2}, \mathrm{pH}, \mathrm{AaDO}_{2}$ and $\mathrm{VEI}$ to resuscitation over an 8 hours period. Evolution of the A) arterial partial pressure of $\mathrm{CO}_{2}\left(\mathrm{pCO}_{2}, \mathrm{~B}\right)$ $\mathrm{pH}, \mathrm{C}) \mathrm{AaDO}_{2}$ and D) ventilation efficient index (VEI). Five groups were compared: congenital diaphragmatic hernia (CDH, $\mathbf{\square}, n=5)$, $\mathrm{CDH}+$ surfactant $(\mathrm{CDH}+\mathrm{SURF},-, n=4), \mathrm{CDH}+$ tracheal occlusion $(\mathrm{CDH}+\mathrm{TO}, \boldsymbol{\Delta}, n=5), \mathrm{CDH}+\mathrm{TO}+\operatorname{SURF}(\boldsymbol{\bullet}, n=6)$, and non-operated controls (Cont, s, $n=4)$. Data is presented as mean \pm SEM where $*=$ different from controls over time, $\#=$ different from $\mathrm{CDH}+\mathrm{TO}$ over time and $+=$ different from $\mathrm{CDH}$ over time $(p<0.05)$.

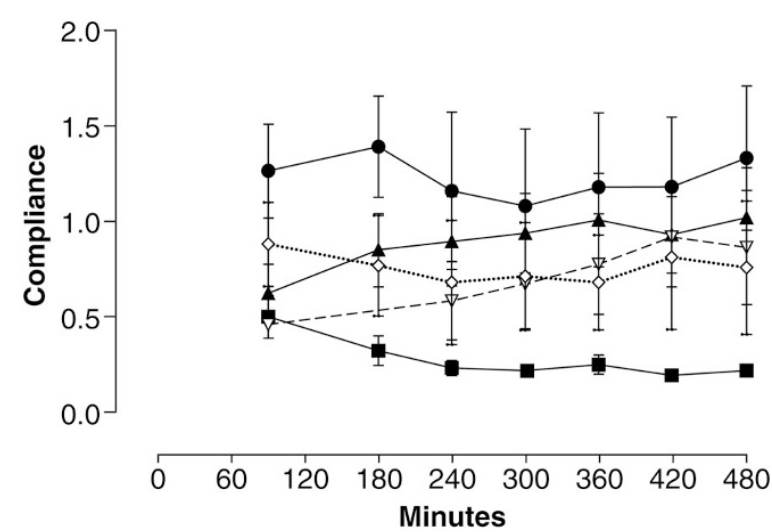

Figure 3. Response of compliance to resuscitation over an 8 hours period. Five groups were compared: congenital diaphragmatic hernia $(\mathrm{CDH}, n=3)$, $\mathrm{CDH}+$ surfactant $(\mathrm{CDH}+\mathrm{SURF}, n=4), \mathrm{CDH}+$ tracheal occlusion $(\mathrm{CDH}+\mathrm{TO}, n=5), \mathrm{CDH}+\mathrm{TO}+\mathrm{SURF}(n=6)$, and non-operated controls (Cont, $n=3$ ). Data is presented as mean \pm SEM. Differences are not statistically significant.

in the $\mathrm{CDH}+\mathrm{SURF}$ group versus $\mathrm{CDH}$ lambs, even though not statistically significant, suggests that exogenous surfactant may have some beneficial effects on $\mathrm{CDH}$.

Our results are in accordance with a previous study that examined the role of surfactant supplementation in $\mathrm{CDH}$ (30) even though the beneficial effects appear modest when compared with the effects of tracheal occlusion. As published previously, $\mathrm{pH}$ is improved significantly by surfactant treatment at birth in the CDH lamb model (30). Our inability to demonstrate a decrease in $\mathrm{PCO}_{2}$ after exogenous surfactant may be related to a different ventilation strategy. In addition, Wilcox's study had a resuscitation period of only $4 \mathrm{~h}$, and no control groups were used for comparison (30). Our study shows that the limited effect of exogenous surfactant failed to translate into significant beneficial effects with respect to ease of ventilation or oxygen diffusion over $8 \mathrm{~h}$. It is possible that a longer observation period is needed to show any beneficial effect.

Overall, the current data suggest that fetal TO continues to yield the best results in terms of overall postnatal lung function. The data further support the notion that this outcome is likely due to surfactant independent mechanisms. These mechanisms include reversal of pulmonary hypoplasia along with lung and pulmonary artery remodeling. The associated lung remodeling, by altering the collagen:elastin ratio and decreasing alveolar wall thickness, results in greater alveolar distension, which leads to increased lung compliance. In addition, the decreased area of the media of small arteries observed in $\mathrm{CDH}+\mathrm{TO}$ (7) may decrease the ventilation/perfusion mismatch. In this study, accelerated prenatal lung growth, along with lung and artery remodeling, rather than repletion of surfactant levels at birth, appears more important in improving postnatal lung function in lambs with a surgically created $\mathrm{CDH}$.

Fetal intervention is not without risk for either the fetus or mother $(35,48)$. The rationale for any prenatal intervention for a fetus with $\mathrm{CDH}$ is to improve postnatal outcome with the respect to the present success of conservative management (49). This can potentially be achieved either by selecting a 
Table 2. Statistical comparisons for longitudinal data presented in figure 2

\begin{tabular}{lcccc}
\hline & CDH vs & CDH + TO vs & Controls vs & Controls vs \\
& CDH + SURF & CDH + TO + SURF & CDH + SURF & CDH + TO + SURF \\
\hline $\mathrm{pH}$ & $\mathbf{0 , 0 0 3}(<)$ & 0,320 & 0,076 & 0,180 \\
$\mathrm{PCO}_{2}$ & 0,965 & 0,157 & $\mathbf{0 , 0 1 1}(<)$ & $\mathbf{0 , 0 1 2}(<)$ \\
$\mathrm{AaDO}_{2}$ & 0,417 & 0,417 & 0,974 & 0,988 \\
$\mathrm{VEI}$ & 0,279 & $\mathbf{< 0 , 0 0 1}(>)$ & $\mathbf{0 , 0 0 1}(>)$ & $<$ \\
Compliance & 0,746 & 0,746 & 0,746 & $0,877(>)$ \\
\hline
\end{tabular}

$\mathrm{p}$ value for each comparison. For each parameter, four comparisons were made and the Bonferroni procedure was used to correct for the level of significance: for an $\alpha \leq 0,05, \mathrm{p}$ should be $\leq 0,012$. Significant comparisons are highlighted in bold. $(>)$ or $(<)$ indicates if the first-listed group is significantly higher $(>)$ or lower $(<)$ than the second group.

subgroup with an extremely high risk of mortality $(50,51)$ and/or by improving the technical aspects of the proposed intervention. Given the nature of this disease and the complexity of its treatment, it is essential to pursue studies in animal models to assess both the short-term mortality and the longterm morbidity.

Acknowledgments. The authors thank Lucile Turcot and Tommy Seaborn for their help with the statistical analysis.

\section{REFERENCES}

1. Thibeault DW, Haney B 1998 Lung volume, pulmonary vasculature, and factors affecting survival in congenital diaphragmatic hernia. Pediatrics 101:289-295

2. Thebaud B, de Lagausie P, Forgues D, Mercier JC 1998 [Congenital diaphragmatic hernia. I. Simple defect of the diaphragm or anomaly of the pulmonary mesenchyme?] Arch Pediatr 5:1009-1019

3. Thebaud B, Saizou C, Farnoux C, Hartman JF, Mercier JC, Beaufils F 1999 [Congenital diaphragmatic hernia. II. Is pulmonary hypoplasia an indefinable obstacle?] Arch Pediatr 6:186-198

4. Bratu I, Flageole H, Laberge JM, Possmayer F, Harbottle R, Kay S, Khalife S, Piedboeuf B 2001 Surfactant levels after reversible tracheal occlusion and prenatal steroids in experimental diaphragmatic hernia. J Pediatr Surg 36:122-127

5. Harrison MR, Mychaliska GB, Albanese CT, Jennings RW, Farrell JA, Hawgood S, Sandberg P, Levine AH, Lobo E, Filly RA 1998 Correction of congenital diaphragmatic hernia in utero. IX: Fetuses with poor prognosis (liver herniation and low lung-to-head ratio) can be saved by fetoscopic temporary tracheal occlusion. J Pediatr Surg 33:1017-1023

6. Wu J, Ge X, Verbeken EK, Gratacos E, Yesildaglar N, Deprest JA 2002 Pulmonary effects of in utero tracheal occlusion are dependent on gestational age in a rabbit model of diaphragmatic hernia. J Pediatr Surg 37:11-17

7. Bratu I, Flageole H, Laberge JM, Chen MF, Piedboeuf B 2001 Pulmonary structura maturation and pulmonary artery remodeling after reversible fetal ovine tracheal occlusion in diaphragmatic hernia. J Pediatr Surg 36:739-744

8. Piedboeuf B, Laberge JM, Ghitulescu G, Gamache M, Petrov P, Belanger S, Chen MF, Hashim E, Possmayer F 1997 Deleterious effect of tracheal obstruction on type II pneumocytes in fetal sheep. Pediatr Res 41:473-479

9. Lines A, Nardo L, Phillips ID, Possmayer F, Hooper SB 1999 Alterations in lung expansion affect surfactant protein $\mathrm{A}, \mathrm{B}$, and $\mathrm{C}$ mRNA levels in fetal sheep. Am J Physiol 276:L239-L245

10. De Paepe ME, Johnson BD, Papadakis K, Luks FI 1999 Lung growth response afte tracheal occlusion in fetal rabbits is gestational age-dependent. Am J Respir Cell Mol Biol 21:65-76

11. Flecknoe S, Harding R, Maritz G, Hooper SB 2000 Increased lung expansion alter the proportions of type I and type II alveolar epithelial cells in fetal sheep. Am J Physiol Lung Cell Mol Physiol 278:L1180-L1185

12. Glick PL, Stannard VA, Leach CL, Rossman J, Hosada Y, Morin FC, Cooney DR, Allen JE, Holm B 1992 Pathophysiology of congenital diaphragmatic hernia II: the fetal lamb CDH model is surfactant deficient. J Pediatr Surg 27:382-388

13. Suen HC, Catlin EA, Ryan DP, Wain JC, Donahoe PK 1993 Biochemical immaturity of lungs in congenital diaphragmatic hernia. J Pediatr Surg 28:471-477

14. Alcorn D, Adamson TM, Lambert TH 1977 Morphologic effects of chronic tracheal ligation and drainage in the fetal lamb lung. J Anat 123:649-660

15. Benachi A, Chailley-Heu B, Barlier-Mur AM, Dumez Y, Bourbon J 2002 Expression of surfactant proteins and thyroid transcription factor 1 in an ovine model of congenital diaphragmatic hernia. J Pediatr Surg 37:1393-1398

16. Glick PL, Leach CL, Besner GE, Egan EA, Morin FC, Malanowska Kantoch A Robinson LK, Brody A, Lele AS, McDonnell M, Holm B, Rodgers BT, Msall ME, Courey NG, Karp MP, Allen JE, Jewett Jr TC, Cooney DR 1992 Pathophysiology of congenital diaphragmatic hernia. III: Exogenous surfactant therapy for the high-risk neonate with CDH. J Pediatr Surg 27:866-869

17. Ijsselstijn H, Zimmermann LJ, Bunt JE, de Jongste JC, Tibboel D 1998 Prospective evaluation of surfactant composition in bronchoalveolar lavage fluid of infants with congenital diaphragmatic hernia and of age-matched controls. Crit Care Med 26:573580
18. Asabe K, Tsuji K, Handa N, Kurosaka N, Kajiwara M 1997 Immunohistochemical distribution of surfactant apoprotein-A in congenital diaphragmatic hernia. J Pediatr Surg 32:667-672

19. Schnitzer JJ, Hedrick HL, Pacheco BA, Losty PD, Ryan DP, Doody DP, Donahoe PK 1996 Prenatal glucocorticoid therapy reverses pulmonary immaturity in congenital diaphragmatic hernia in fetal sheep. Ann Surg 224:430-439

20. Hedrick HL, Kaban JM, Pacheco BA, Losty PD, Doody DP, Ryan DP, Manganaro TF, Donahoe PK, Schnitzer JJ 1997 Prenatal glucocorticoids improve pulmonary morphometrics in fetal sheep with congenital diaphragmatic hernia. J Pediatr Surg 32:217-222

21. Ijsselstijn H, Pacheco BA, Albert A, Sluiter W, Donahoe PK, De Jongste JC, Schnitzer JJ, Tibboel D 1997 Prenatal hormones alter antioxidant enzymes and lung histology in rats with congenital diaphragmatic hernia. Am J Physiol 272:L1059L1065

22. Oue T, Shima H, Taira Y, Puri P 2000 Administration of antenatal glucocorticoids upregulates peptide growth factor gene expression in nitrofen-induced congenital diaphragmatic hernia in rats. J Pediatr Surg 35:109-112

23. Shima H, Oue T, Taira Y, Miyazaki E, Puri P 2000 Antenatal dexamethasone enhances endothelin receptorB expression in hypoplastic lung in nitrofen-induced diaphragmatic hernia in rats. J Pediatr Surg 35:203-207

24. Shima H, Ohshiro K, Taira Y, Miyazaki E, Oue T, Puri P 1999 Antenatal dexamethasone suppresses tumor necrosis factor-alpha expression in hypoplastic lung in nitrofen-induced diaphragmatic hernia in rats. Pediatr Res 46:633-637

25. Taira Y, Oue T, Shima H, Miyazaki E, Puri P 1999 Increased tropoelastin and procollagen expression in the lung of nitrofen-induced diaphragmatic hernia in rats. J Pediatr Surg 34:715-719

26. Oue T, Taira Y, Shima H, Miyazaki E, Puri P 1999 Effect of antenatal glucocorticoid administration on insulin-like growth factor I and II levels in hypoplastic lung in nitrofen-induced congenital diaphragmatic hernia in rats. Pediatr Surg Int 15:175-179

27. Oue T, Yoneda A, Shima H, Taira Y, Puri P 2002 Increased vascular endothelial growth factor peptide and gene expression in hypoplastic lung in nitrofen induced congenital diaphragmatic hernia in rats. Pediatr Surg Int 18:221-226

28. Bratu I, Flageole H, Laberge JM, Kovacs L, Faucher D, Piedboeuf B 2004 Lung function in lambs with diaphragmatic hernia after reversible fetal tracheal occlusion. J Pediatr Surg 39:1524-1531

29. Davey MG, Hedrick HL, Bouchard S, Mendoza JM, Schwarz U, Adzick NS, Flake AW 2003 Temporary tracheal occlusion in fetal sheep with lung hypoplasia does not improve postnatal lung function. J Appl Physiol 94:1054-1062

30. Wilcox DT, Glick PL, Karamanoukian H, Rossman J, Morin FC 3rd, Holm BA 1994 Pathophysiology of congenital diaphragmatic hernia. V. Effect of exogenous surfactant therapy on gas exchange and lung mechanics in the lamb congenital diaphragmatic hernia model. J Pediatr 124:289-293

31. O'Toole SJ, Karamanoukian HL, Sharma A, Morin FC 3rd, Holm BA, Azizkhan RG, Glick PL 1996 Surfactant rescue in the fetal lamb model of congenital diaphragmatic hernia. J Pediatr Surg 31:1105-1109

32. Lotze A, Knight GR, Anderson KD, Hull WM, Whitsett JA, O'Donnell RM, Martin G, Bulas DI, Short BL 1994 Surfactant (beractant) therapy for infants with congenital diaphragmatic hernia on ECMO: evidence of persistent surfactant deficiency. J Pediatr Surg 29:407-412

33. Kendig JW, Notter RH, Cox C, Reubens LJ, Davis JM, Maniscalco WM, Sinkin RA, Bartoletti A, Dweck HS, Horgan MJ, Risemberg H, Phelps DL, Shapiro DL 1991 A comparison of surfactant as immediate prophylaxis and as rescue therapy in newborns of less than 30 weeks' gestation. N Engl J Med 324:865-871

34. McCabe AJ, Wilcox DT, Holm BA, Glick PL 2000 Surfactant-a review for pediatric surgeons. J Pediatr Surg 35:1687-1700

35. Harrison MR, Keller RL, Hawgood SB, Kitterman JA, Sandberg PL, Farmer DL, Lee H, Filly RA, Farrell JA, Albanese CT 2003 A randomized trial of fetal endoscopic tracheal occlusion for severe fetal congenital diaphragmatic hernia. N Engl J Med 349:1916-1924

36. de Luca U, Cloutier R, Laberge JM, Fournier L, Prendt H, Major D, Edgell D, Roy PE, Roberge S, Guttman FM 1987 Pulmonary barotrauma in congenital diaphragmatic hernia: experimental study in lambs. J Pediatr Surg 22:311-316

37. Flageole H, Evrard VA, Vandenberghe K, Lerut TE, Deprest JA 1997 Tracheoscopic tracheal occlusion in the ovine model: possible application in congenital diaphragmatic hernia. J Pediatr Surg 32:1329-1331 
38. Jenkin G, Jorgensen G, Thorburn GD, Buster JE, Nathanielsz PW 1985 Induction of premature delivery in sheep following infusion of cortisol to the fetus. I. The effect of maternal administration of progestagens. Can J Physiol Pharmacol 63:500-508

39. Ikegami M, Polk D, Jobe A 1996 Minimum interval from fetal betamethasone treatment to postnatal lung responses in preterm lambs. Am J Obstet Gynecol 174:1408-1413

40. Ennema JJ, Kobayashi T, Robertson B, Curstedt T 1988 Inactivation of exogenous surfactant in experimental respiratory failure induced by hyperoxia. Acta Anaesthesiol Scand 32:665-671

41. Fracica PJ, Caminiti SP, Piantadosi CA, Duhaylongsod FG, Crapo JD, Young SL 1994 Natural surfactant and hyperoxic lung injury in primates. II. Morphometric analyses. J Appl Physiol 76:1002-1010

42. Huang YC, Caminiti SP, Fawcett TA, Moon RE, Fracica PJ, Miller FJ, Young SL, Piantadosi CA 1994 Natural surfactant and hyperoxic lung injury in primates. I. Physiology and biochemistry. J Appl Physiol 76:991-1001

43. Holm BA, Notter RH, Siegle J, Matalon S 1985 Pulmonary physiological an surfactant changes during injury and recovery from hyperoxia. J Appl Physio 59:1402-1409

44. Payne NR, Kriesmer P, Mammel M, Meyer CL 1991 Comparison of six ECMO selection criteria and analysis of factors influencing their accuracy. Pediatr Pulmonol $11: 223-232$
45. Bohn D, Tamura M, Perrin D, Barker G, Rabinovitch M 1987 Ventilatory predictors of pulmonary hypoplasia in congenital diaphragmatic hernia, confirmed by morphologic assessment. J Pediatr 111:423-431

46. Bin Saddiq W, Piedboeuf B, Laberge JM, Gamache M, Petrov P, Hashim E, Manika A, Chen MF, Belanger S, Piuze G 1997 The effects of tracheal occlusion and release on type II pneumocytes in fetal lambs. J Pediatr Surg 32:834-838

47. Kay S, Laberge JM, Flageole H, Richardson S, Belanger S, Piedboeuf B 2001 Use of antenatal steroids to counteract the negative effects of tracheal occlusion in the fetal lamb model. Pediatr Res 50:495-501

48. Flake AW, Crombleholme TM, Johnson MP, Howell LJ, Adzick NS 2000 Treatment of severe congenital diaphragmatic hernia by fetal tracheal occlusion: clinical experience with fifteen cases. Am J Obstet Gynecol 183:1059-1066

49. Bohn D 2002 Congenital diaphragmatic hernia. Am J Respir Crit Care Med 166:911915

50. Lipshutz GS, Albanese CT, Feldstein VA, Jennings RW, Housley HT, Beech R, Farrell JA, Harrison MR 1997 Prospective analysis of lung-to-head ratio predicts survival for patients with prenatally diagnosed congenital diaphragmatic hernia. J Pediatr Surg 32:1634-1636

51. Metkus AP, Filly RA, Stringer MD, Harrison MR, Adzick NS 1996 Sonographic predictors of survival in fetal diaphragmatic hernia. J Pediatr Surg 31:148-152 